\title{
IV. Experiments to ascertain whether there exists any affinity betwixt carbon and clay, lime and silex, separately or as compounds united with the oxide of iron forming iron ores and iron stones
}

\section{David Mushet Esq}

To cite this article: David Mushet Esq (1804) IV. Experiments to ascertain whether there exists any affinity betwixt carbon and clay, lime and silex, separately or as compounds united with the oxide of iron forming iron ores and iron stones, Philosophical Magazine Series 1, 20:77, 31-36, DOI: $10.1080 / 14786440408676591$

To link to this article: http://dx.doi.org/10.1080/14786440408676591

\section{Published online: 18 May 2009.}

Submit your article to this journal ए

\section{Џ Article views: 2}

Q View related articles ¿ 
their application. Through their assistance we become acquainted with some of the laws by which the omniscient and eternal Creator governs the universe, and are enabled to predict their effects in distant ages. Our condition becomes superior to the common lot of humanity, and we may be held out to the world as an example of the perfection to which it is possible for the human species to arrive. Arnold, Nottinghamshire,

October $13,1804$.

IV. Experiments to ascertain whether there exists anij Affnity betwixt Carbon and Clay, Lime and Silex, separately or as Compounds united with the Oxide of Irot forming Iron Ores and Iron Stones. By David Mvesat, Esq. of the Calder Iron-Works.

[Continued from our last volume, p. 344.]

$\mathrm{U}_{\text {NDER }}$ the same class of mixture the following experiments were performed:

VIII. Pure silex six parts, or $\quad+120 \mathrm{grs}$.

Oxide of iron four parts, or - 80

Charcoal 1-40th of the compound, or 5

This mixture was very perfectly reduced, and glass obtained whose surface possessed a clouded coppery green colour. The fracture showed a much less perfect, though dense glass, the colour of which was a rusty yellowish green. Beneath was found a very neat sphetnle of malleable iron which weighed 12 grains, and equal to 6 per cent.
IX. Pure silex
120 grs.
Oxide of iron - $\quad$ - 80
Charcoal 1-20th, or - 10

The result of the fusion of this mixture was a glase sit milar, though more perfect throughout, to the former. A fine metallic button was found below the glass which weighed 22 grains, and equal to 11 per cent.
$X$. Pure silex
Oxide of iron
$190 \mathrm{grs}$.
Charcoal, 1-10th, or - 20

This mixture approached somewhat to infusibility. A rough half vitrified green mass, very cellular, was found in the crucible. Two pieces of iron were found which weighed 26 grains, equal to 13 per cent. The colour of the earthy parts was a rich green mixed and spotted with rusty yellow. 


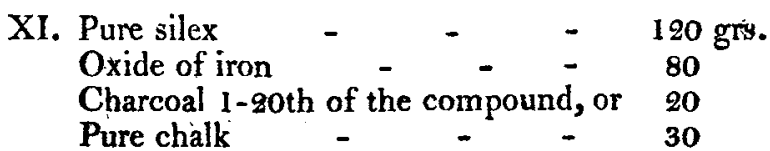

The fusion of this mixture afforded a very beautiful glass of a rich brown blackish colour, possessed of great smoothness and lustre. Beneath was found an elegant crystallized metallic button which weighed 50 grains; equal to 25 per cent. from the mixture.

In this experiment again, as in others formerly recorded, we have a direct proof of the useful agency of calcareous earth in the reduction and separation of iron from its earthy combinations.

Recapitulation of experiments with siliceous matter and oxide of iron in the proportion of six of the former to four of the latter.

Exp. II. 1-40th of charcoal yielded 14 per cent.

1II. $1-25$ th ditto. - $7 \frac{4}{10}$

IV. 1-20th ditto $\longrightarrow 9$

V. 1-15th ditto -13

VI. 1-10th ditto not fused 12,.5

VII. Being No. VI. repeated, with the addition of 80 grains of chalk, ${ }^{20} \frac{2}{10}$

VIII. With pure silex,

1-40th of charcoal yielded 6 per cent.

IX. 1-20th ditto 11

$X$. 1-10th ditto not fused 13

XI. Being No. X. repeated, with the addition of 30 grains of pure lime, 25 per cent.

One very abvious fact marks this table, namely, a great difference betwixt the quantity of iron revived when sand and pure silex were used. It may be proper here to remark, that Exp. VIII, IX, X, XI, where pure silex was used, were performed in crucibles made of Cornwall clay. If, therefore, there exists any tendency in clay under high temperatures to absorb the oxygen of the oxide, which I have suspected sometimes to have been the case; and if this affinity is exerted in proportion to the purity of the clay; a partial deoxidation of the oxide in these experiments may account for a larger portion of metal being revived with the same proportion of charcoal.

Third class of compounded ores consisted of

Well prepared chalk, six parts,

Oxide, four parts. 
I. Mixture

Charcoal 1-40th, or - $-\overline{1}$ - $12 \frac{1}{2}$
A black rough earthy glass was obtained by the fusion

500 grs. of this mixture, not unlike a furnace cinder. It was carefully examined, but without finding any trace of revived metal.

$\begin{array}{llll}\text { II. Mixture } & - & - & 500 \mathrm{grs} \\ \text { Charcoal } 1-30 \mathrm{th} \text {, or } & - & - & 166_{10}^{6}\end{array}$

The glass obtained at this time was more perfect, glassy, and shining upon the surface. The interior very like finery cinder. There appeared no vestige of revived iron.

III. The same as before, performed with 1-20th, or 25 grains of charcoal. The glass had assumed a considerable portion of lustre and a few pearly shades upon the surface, but still there appeared no metallic produce.

IV. Mixture

500 grs.

Charcoal 1-15th, or

33

A very perfect mass of glass was obtained by the fusion of this mixture. The surface was black, smooth, and shining: the fracture dense and opake. A neat metallic spherule was found which weighed 17 grains; equal to $3 \frac{1}{2}$ per cent. The corrresponding experiment as to carbon with clay yielded 63 grains, and with silex 63 and 65 of iron.
V. Mixture
Charcoal 1-10th, or
$500 \mathrm{grs}$.
50

A perfect fusion and fine black glass were obtained, accompanied by a flattish metallic button of iron which weighed 58 grains; equal to $11 \frac{6}{10}$ per cent.

VI. Mixture

Charcoal 1-7th, or neariy

500 grs.

72

A dark rich green glass was obtained in this fusion, and 2 bright silvery-coloured metallic button which weighed 124 grains; equal to $24 \frac{8}{10}$ per cent.

$\begin{array}{lll}\text { VII. Mixture } & - & 500 \text { grs. } \\ \text { Charcoal 1-5th, or } & - & \text { - }\end{array}$

This mixture fused, and yielded a fine crystallized button of steel. It was found to weigh - - 120 grs. Globules thrown up against the top and sides

of the crucible during ebullition - $\quad 10$

Equal to 26 per cent. Total $\frac{180}{}$

The colour of the glass was light blueish green, very transparent in thin fragments.

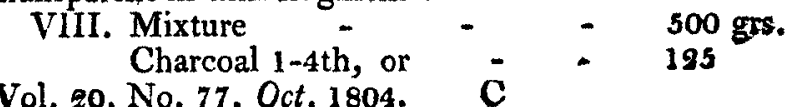

The 
The greatest part of this compound was reduced to perfect fusion. A small portion was found intimately connected, but in the state of a powder, upon the surface of the glass. The metallic button was similar to the last, and weighed - $\quad-\quad$ - 120 grs. Globules collected - $\quad-\quad 5$

Equal to 25 per cent. Total $\overline{\mathbf{1 9 5}}$

The glass was still more transparent than in the former experiment. The green tinge had entirely disappeared, and was succeeded by a lead blue colour, which always manifests itself when the separation of the metallic particles has been complete.

Recapitulation of experiments with chalk and oxide of iron in the proportion of six of the former to four of the latter.

Exp. I. 1-40th of charcoal, no iron revived.

\begin{tabular}{|c|c|c|c|}
\hline II. 1 -3oth & ditto & & itto \\
\hline 1II. $1-20$ th & ditto & & itto \\
\hline IV. 1-15th & ditto & yiclded & $3 \frac{1}{2}$ per cent. \\
\hline V. 1-10th & ditto & & $11_{-f_{1}^{\prime}}^{f_{0}}$ \\
\hline VI. $1-7^{\text {th }}$ & ditte & & $24 \frac{8}{10}$ \\
\hline $\begin{array}{l}\text { I1. } 1-5 \text { th } \\
\text { II. } 1-4 \text { th }\end{array}$ & & & 26 \\
\hline
\end{tabular}

The following table of comparison will, at one view, exhibit the very various results that take place in the process of separation, effected entirely by the nature of the earths, which in all cases must inevitably form a chief component part of our iron ores and iton stones.

General Table of the Results of the Fusion of Clay, Silex, and Lime, and Oxide of Iron, with various Proportions of Charcoal.

\begin{tabular}{|c|c|c|c|c|c|c|}
\hline \multirow[b]{2}{*}{$\begin{array}{l}\text { Pioportions } \\
\text { ot Char- } \\
\text { coal. }\end{array}$} & \multicolumn{2}{|c|}{ CLAY. } & \multicolumn{2}{|c|}{$S_{I h} \cdot x$. } & \multicolumn{2}{|c|}{ LIMf. } \\
\hline & $\begin{array}{l}\text { Grains } \\
\text { of iron } \\
\text { revived. }\end{array}$ & $\begin{array}{l}\text { Produce } \\
\text { per } \\
\text { cent. }\end{array}$ & $\begin{array}{l}\text { Grans } \\
\text { of iron } \\
\text { revived. }\end{array}$ & $\begin{array}{l}f^{2} \text { roduct } \\
\text { per } \\
\text { tent. }\end{array}$ & $\begin{array}{l}\text { Gioias } \\
\text { of iron } \\
\text { revived. }\end{array}$ & $\begin{array}{l}\text { Produci } \\
\text { per } \\
\text { cent. }\end{array}$ \\
\hline $1-40$ th & 14 & $2 \frac{8}{10}$ & 7 & $1_{-18}^{4}$ & & \\
\hline $1-25$ th & 46 & $9_{\top \pi}^{0}$ & 37 & $7+4$ & .. & $\cdots \cdots$ \\
\hline $1-13$ th & 63 & $12 \frac{6}{10}$ & 65 & 13 & 17 & $3 \frac{1}{2}$ \\
\hline 1-10th & not fa- & sible & not fu- & sible & 58 & $.11 \frac{6}{30}$ \\
\hline $1-7$ th & ditto & ditto & ditto & ditto & 124 & $24 \frac{8}{10}$ \\
\hline $1-\not t$ & ditto & ditto & ditto & ditto & 130 & \\
\hline
\end{tabular}


Were we to proceed to reason on what this variety of result depends, and referring to the experiments formerly communicated, we should have expected that clay and silex, each absorbing a considerable portion of carbon, would have required a greater dose in the experiments with oxide to have let fall the first portion of iron; and that, as calcareous earth betokened no affinity manifested in a similar manner to carbon, ores thus compounded would have let fall their metallic contents with the most minute comparative quantity of carbon.

The reverse of all this turns out to be the fact: for the argillaceous and siliteous compounds separate iron with the smallest portion of carbon; the calcareous compound requiring three times as much.

Hitherto we have discovered no direct active principle in calcareous earth, acting as a stimulant to the existing affinities betwixt carbon and iron, beyond facilitating, almost under every circumstance, the perfect fusion of the compound. If we suppose it to remain neutral in this respect, then, to explain the phænomenon of the argillaceous and siliceous compounds, we must suppose an active principle exerted by each of these earths, nearly in the same ratio, upon the oxide of iron, decompounding the oxide, and either liberating the oxygen or uniting with it. The removal of this immediately constitutes an affinity betwixt the particles of iron and the entire portion of carbon, the consequence of which is the revival of the iron.

That these conjectures are well founded, may be gathered from experiments similar to the following:

Calcareous earth six parts, or - $\quad 120 \mathrm{grs}$.

Oxide four parts, or - $\quad-\quad-80$

Charcoal 1-15th of the whole - $\quad$ - 131.

To this were added of Cornwall clay - 120

From the fusion of this mixture a neat metallic spherule was obtained which weighed 10 grains, and was equal to 5 per cent. This is the same, with regard to proportion, as Experiment IV, third class, with the addition of 120 grains clay; and it appears a fair consequence that $1 \frac{1}{2}$ per cent. of inore iron was revived.

There appears still another way by which we may in part account for the early separation of iron from the argillaceous and siliceous compounds.

In a former part of this inquiry it was shown that the combination of carbon with clay and silex did not produce full effect unless the latter entered into fusion; and it is evident from the foregoing experiments, that the compounds formed with

$$
\mathrm{C}_{2} \text { oxide }
$$


oxide and clay are more infusible than those formed by lime. The particles of clay and silex, therefore, being the last to enter into fusion, must be the last to exert their affinities upon the carbon. This being unacted upon, except by the oxide, readily unites first to carry off the oxygen, and next to impregnate the iron with carbonaceous matter.

If this takes place at an early stage of the operation, it is evident that the metallic result may be formed in consequence of the entire combination of the carbon before the earths have entered into fusion.

The quantity of carbon which the oxide of the calcareous compound takes up before any metal is allowed to fall, remains still unexplained, and appears a curious and very important faet, which cannot be solved by the last hypothesis. The presence of lime seems to prevent the immediate action of the metallic particles upon the carbon, but directs the whole force of the latter to the removal of the oxygen. By this means, however, it secures in the end a richer and more plentiful harvest of metal from ores similarly compounded.

The progressive stages of metallization are marked, in many instances, with a greater proportion of produce than in experiments with argillaceous and siliceous ores.

In the 1st class, the increase of the produce in iron, see

Exps. II and III, was 17 grs. for $8 \frac{1}{3}$ carbon

In the $2 \mathrm{~d}$ class, - IV and $\mathrm{V},-21-\$ \frac{1}{3}$

In the $3 \mathrm{~d}$ class,

or calcareous, $-\mathrm{V}$ and $\mathrm{VT},-66-22$

[Yo be continued.]

V. Letter from Dr. Thopston to Mr. Tilloch on the Cow-Pox; with an Account of the Cases in Fulwood's Rents.

DEAR SIR,

No, 1, Hind-street, Manchester-square, October 15, 1804 .

$T_{\text {HE subject of the cow-pock is of such general interest, }}$ that I shall delay my fifth letter to Mr. Arthur Aikin, to say a few words on the late cases of supposed small-pox after the cow-pock inoculation so generally known in this metropolis.

Dr. Lettsom, in a letter to me on the receipt of my work entitled "Facts decisive in favour of the Cow-pock," which I presented to him, says, "that after what has been written by me and others on yaccination, the practitioner who now 